\title{
Analysis of nortriptyline's prophylaxis on hemodialysis headache patients - a pilot study
}

\section{Análise de profilaxia da nortriptyline em hemodiális de pacientes com enxaqueca - estudo piloto}

\author{
Bruna Mendonça Lima', Paulo Sergio Faro Santos², Alan Chester Feitosa de Jesus ${ }^{3}$ \\ 'Neurologist, Member of the Brazilian Headache Society \\ ${ }^{2}$ Resident medical, Department of Neurology, Neurological Institute of Curitiba: \\ Member of the Brazilian Headache Society \\ ${ }^{3}$ Neurologist, Member of the Brazilian Headache Society; Member of the Brazilian Neurology Academy
}

Lima BM, Santos PSF, Jesus ACF. Analysis of nortriptyline's prophylaxis on hemodialysis headache patients a pilot study. Headache Medicine. 2016;7(1):23-7

\begin{abstract}
Background: Headache is the most common neurological symptom of patients on hemodialysis treatment. However, this condition is usually treated only after the pain has already begun. Objective: Determine the efficacy and tolerability of nortriptyline as a prophylactic treatment for patients diagnosed with hemodialysis headache. Methods: This study is an open and a prospective clinical trial. Twelve patients with hemodialysis headache were studied in this trial. They were asked to take nortriptyline (25 mg per day) during three months as a prophylaxis for their headaches. Weekly interviews were made to register eventual headaches. Additionally, other clinical features were analyzed such as the intensity of pain, its location, side effects of the drug and use of abortive medications. Results: There was a significant reduction $(p<0.05)$ in the intensity as well as frequency of pain. The duration of the episodes also decreased. Conclusions: Our findings suggest that nortriptyline $25 \mathrm{mg}$ is capable of reducing not only the frequency, but also the intensity of the pain in the hemodialysis headache. However, further studies are necessary.
\end{abstract}

Keywords: Prophylaxis; Nortriptyline; Headache; Dialysis

\section{RESUMO}

Introdução: Cefaleia é o sintoma mais comum dos pacientes em tratamento com hemodiálise. Porém, esta condição normlmente é tratada apenas depois da dor ter iniciado. Objetivo: Determinar a eficácia da nortriptilina como um tratamento profilático para paciente diagnosticados com cefaleia da diálise. Métodos: Este estudo é um ensaio clínico aberto e prospective. Doze pacientes com cefaleia da diálise foram estudados neste ensaio. Eles foram convidados a tomar nortriptilina (25mg por dia) durante três meses como profilaxia para a cefaleia. Entrevistas semanais foram realizadas para registrar eventuais episódios de cefaleia. Além disso, outras características clínicas foram analizadas, tais como intensidade da dor, localização, efeitos adversos da medicação e uso de medicação abortiva. Resultados: Houve redução estatisticamente significativa $(p<0.05)$ da intensidade e da frequência da dor. A duração dos episódios também reduziram. Conclusão: Nossos achados sugerem que a nortriptilina $25 \mathrm{mg}$ é capaz de reduzir não apenas a frequência, mas também a intensidade da dor na cefaleia da diálise. Entretanto, mais estudos são necessários.

Palavras-chave: Profilaxia; Nortriptilina; Cefaleia; Diálise

\section{INTRODUCTION}

According to Kidney Disease Outcomes Quality Initiative, renal insufficiency is the final stage (from five) of chronic renal disease (CRD) and it is characterized by a reduction of glomerular filtration rate to values lower than $60 \mathrm{~mL} / \mathrm{min} / 1.73 \mathrm{~m}^{2}$ for three months or more, regardless of the cause of the decreased function. In this stage, substitutive renal therapies, such as peritoneal dialysis, hemodialysis and continued substitutive renal therapy, are 
recommended. (1) In 2009, a study in Brazil showed that 77.589 patients were on dialytic therapy and $93 \%$ of them received hemodialysis. (2)

Headache is the most frequent neurological symptom of hemodialytic patients, diagnosed in $56 \%$ of them. The pharmacological treatment for this pain is dipirone. Nevertheless, in $14 \%$ of these patients, no options of treatment are mentioned. ${ }^{(3)}$ The first study about a specific type of headache related to hemodialysis was published in 1972. This study intended to find causes for the pain's onset by discussing crucial aspects like trigger factors; biochemical and psychological changes secondary to hemodialysis. The kidney's role in pathophysiology of the hemodialysis headache and the influence of other medications used by these patients are also mentioned in this resarch. ${ }^{(4)}$

Only in 1988, the International Headache Society (IHS) published the Classification and Diagnostic Criteria for Headache Disorders, Cranial Neuralgias and Facial Pain recognizing this disease as a headache associated with metabolic abnormalities. ${ }^{(5)}$

The most recent diagnostic criteria are the $3^{\text {rd }}$ edition, beta, the International Classification of Headache published in $2013,{ }^{(6)}$ but as the survey was conducted before this period, we considered the criteria of $2003^{(7)}$ described below. There was no significant change between the two editions.

A. At least three attacks of acute headache fulfilling criteria $C$ and D.

B. Patient is on hemodialysis.

C. Headache develops during at least half of hemodialysis sessions.

D. Headache resolves within 72 hours after each hemodialysis session and/or ceases altogether after successful transplantation.

In previous research, there is only one case report of an attempt to prevent hemodialysis headache. The author of this report used an angiotensin-converting enzyme inhibitor for his patient over ten months with good results during this period. However, after this initial period, the renal function became worse and the therapy had to be discontinued. ${ }^{(8)}$

Nortriptyline is the first metabolic product of amitriptyline, a tricyclic antidepressant which is also used in the control of chronic pains, such as headaches. This drug is capable of blocking norepinephrine reuptake without causing many anticholinergic effects. Therefore, fewer side effects such as excessive somnolence, dry mouth and urinary retention are reported. ${ }^{(9)}$
The objective of this study was to verify the efficacy and tolerability of nortiptyline (25 mg per day) as a prophylactic therapy for hemodialysis headache patients with chronic renal disease who had done hemodialysis at a nephrology clinic in Sergipe.

\section{METHODOLOGY}

This open and prospective clinical trial was conducted in Nephrology Clinic of Sergipe. The trial was divided in two phases: identification of the patients with hemodialysis headache and analysis of their clinical evolution after initiating the prophylactic medication.

Firstly, two hundred and forty eight patients on hemodialysis were selected. One hundred and eighteen of these patients, who were on hemodialytic therapy for more than six months, were interviewed. These patients received three sessions of hemodialysis per week, each session with a mean duration of 4 hours. In the initial evaluation, we tried to identify if they have had headache and the clinical characteristics of each patient's pain: attacks related to hemodialysis, intensity of these attacks according to VAS, location and type of pain, mean duration of the episode, abortive medications usage and presence of interdialytic headache.

In the last phase of this research, patients who fulfilled the diagnostic criteria for hemodialysis headache - those who, in addition, were on hemodialysis for at least six months and were able to see the VAS - were selected. Patients with hemodialysis headache for less than six months or with visual deficiency were excluded from this study. Patients with some cognitive inability, who could not understand the researchers' instructions, were also excluded.

During three-months of follow up (between August and October of 2008), patients were interviewed weekly and the questionnaire was updated with the new data from each of them. The researcher prescribed nortriptilyne's capsules $(25 \mathrm{mg})$ to the patients. The correct usage of such medication was verified every hemodialysis session.

The statistical analysis was gathered using the Statistical Analysis System version 9.1. At the beginning, the researchers provided a descriptive analysis of the data obtained before the treatment ( 12 patients) and then from the data of subsequent evaluations.

After that, the incidence of variables such as frequency, onset, intensity and duration were estimated every month. The average of quantitative variables and the frequency of qualitative variables (use of abortive medications and pain's quality) were also estimated. The Student's t test was applied 
in order to compare the average of the qualitative variables in the initial evaluation with each subsequent month. Then, the data from linear regression of quantitative variables was analyzed considering the three-month treatment.

The Ethic and Research Committee of Federal University of Sergipe approved this study; process number 41.540.000.107-07. All patients included in the study signed a permission term in accordance with Helsinki Declaration rules.

\section{RESULTS}

From the twelve patients diagnosed with hemodialysis headache, according to IHS criteria, at the beginning of the research, eight continued in our study until the end. During the interviews, the most common side effect mentioned was excessive somnolence, reported by $36.36 \%$ of the patients. A patient with a previous complaint of intestinal constipation mentioned such symptom during the evaluations. Besides these symptoms, hypotension, palpitations and vertigo episodes were also mentioned by 9.1\% (one) of the patients.

The location and quality of pain were evaluated in the initial interview as described in Table 1.

Out of the twelve patients interviewed, nine used abortive medication during the attacks. Most of the patients stated that the pain began between the third and fourth hour of hemodialysis; a fact that did not change after the continued use of prophylactic medication.

Table 1 - Pain quality in the initial evaluation

\begin{tabular}{lc}
\hline Quality & Percentage \\
\hline Throbbing frontal & $45.1 \%$ \\
Pressure-like frontal & $18.8 \%$ \\
Burning frontal & $9.1 \%$ \\
Throbbing occipitofrontal & $9.1 \%$ \\
Throbbing parietal & $9.1 \%$ \\
Throbbing temporal & $9.1 \%$ \\
\hline
\end{tabular}

After three months of daily use of nortriptilyne $25 \mathrm{mg}$, the most frequent pain intensity and location were still throbbing frontal (24\%) followed by throbbing temporal (14.29\%), pression-like frontal (12.5\%), burning frontal $(7.14 \%)$, throbbing in vertex $(5.36 \%)$, throbbing occipitofrontal (1.39\%) and pression-like parietal (1.79\%). The average duration of the episode before using prophylactic medication was 5.45 hours and, after the three-month treatment, this parameter changed to 3.15 hours.
A total of one hundred and eighteen interviews were carried out. In sixty-two (52.5\%), the patients denied having pain, but in fifty-six (47.5\%) they related pain. In $60.7 \%$ of positive-pain answers, they mentioned use of abortive medications. The average of the variables - attacks, monthly frequency, onset during hemodialysis, intensity according to VAS and crisis' duration in minutes - are presented in the tables below.

Table 2 - Initial evaluation

\begin{tabular}{lcccccc}
\hline & Mean & SD & $\mathrm{N}$ & Root (N) & SDm & $\mathrm{Cl}$ \\
\hline $\begin{array}{l}\text { Frequency } \\
\text { (attacks/month) }\end{array}$ & 9.3 & 2.2 & 11 & 3.3 & 0.7 & 1.4 \\
Onset (hour) & 3.2 & 1.1 & 11 & 3.3 & 0.3 & 0.7 \\
Intensity (VAS) & 7.5 & 1.8 & 11 & 3.3 & 0.5 & 1.2 \\
Duration (min) & 327 & 324.4 & 10 & 3.2 & 108.3 & 244.7 \\
\hline
\end{tabular}

Table 3 - Evaluation of each month after initiating prophylactic medication

\begin{tabular}{|c|c|c|c|c|c|c|}
\hline & Mean & SD & $\mathrm{N}$ & Root (N) & SDm & $\mathrm{Cl}$ \\
\hline \multicolumn{7}{|l|}{ First month } \\
\hline $\begin{array}{l}\text { Frequency } \\
\text { (attacks/month) }\end{array}$ & 3.3 & 2.3 & 11 & 3.3 & 0.7 & 1.5 \\
\hline Onset (hour) & 3.6 & 0.7 & 10 & 3.2 & 0.2 & 0.5 \\
\hline Intensity (VAS) & 4.4 & 2.6 & 10 & 3.2 & 0.8 & 1.8 \\
\hline Duration (min) & 190.1 & 227.7 & 9 & 3.0 & 75.9 & 175.3 \\
\hline \multicolumn{7}{|l|}{ Second month } \\
\hline $\begin{array}{l}\text { Frequency } \\
\text { (attacks/month) }\end{array}$ & 3 & 2.7 & 10 & 3.2 & 0.8 & 1.9 \\
\hline Onset (hour) & 3.3 & 1.0 & 10 & 3.2 & 0.3 & 0.7 \\
\hline Intensity (VAS) & 5.3 & 2.3 & 10 & 3.2 & 0.7 & 1.6 \\
\hline Duration (min) & 217.4 & 252.6 & 9 & 3.0 & 84.2 & 194.5 \\
\hline \multicolumn{7}{|l|}{ Third month } \\
\hline $\begin{array}{l}\text { Frequency } \\
\text { (attacks/month) }\end{array}$ & 3 & 3.8 & 8 & 2.8 & 1.4 & 3.2 \\
\hline Onset (hour) & 3.8 & 0.2 & 4 & 2.0 & 0.1 & 0.4 \\
\hline Intensity (VAS) & 4 & 1.2 & 4 & 2.0 & 0.6 & 1.8 \\
\hline Duration (min) & 152.3 & 116.8 & 4 & 2.0 & 58.4 & 185.7 \\
\hline
\end{tabular}

Table 4 - Average of all three months

\begin{tabular}{lcccccc}
\hline & Mean & $\mathrm{SD}$ & $\mathrm{N}$ & Root (N) & $\mathrm{SDm}$ & $\mathrm{Cl}$ \\
\hline $\begin{array}{l}\text { Frequency } \\
\text { (attacks/month) }\end{array}$ & 2.8 & 2.4 & 11 & 3.3 & 0.7 & 1.6 \\
Onset (hour) & 3.6 & 0.4 & 11 & 3.3 & 0.1 & 0.3 \\
Intensity (VAS) & 5.0 & 2.1 & 11 & 3.3 & 0.6 & 1.4 \\
Duration (min) & 198.9 & 210.2 & 10 & 3.2 & 66.5 & 150.2 \\
\hline
\end{tabular}

After data analysis with the Student's t test, we observed that there was a significant reduction $(p<0.05)$ in the intensity and an even more significant reduction $(p<0.01)$ in the frequency of the attacks (Table 5). 
Table 5 - Analysis of three-month data with Student's t test

\begin{tabular}{lcccc}
\hline & $\begin{array}{c}\text { Comparison between } \\
\text { the initial evaluation } \\
\text { and first month }\end{array}$ & $\begin{array}{c}\text { Comparison between } \\
\text { the initial evaluation } \\
\text { and second month }\end{array}$ & $\begin{array}{c}\text { Comparison between } \\
\text { the initial evaluation } \\
\text { and third month }\end{array}$ & $\begin{array}{c}\text { Comparison between } \\
\text { the initial evaluation } \\
\text { and average of all } \\
\text { three-months }\end{array}$ \\
\hline $\begin{array}{l}\text { Frequency } \\
\text { (attacks/month) }\end{array}$ & $<0.0001$ & $<0.0001$ & $<0.0005$ & $<0.0001$ \\
Onset (hour) & 0.3031 & 0.6555 & 0.2506 & 0.2817 \\
Intensity (VAS) & 0.0055 & 0.0358 & 0.0092 & 0.0075 \\
Duration (min) & 0.3252 & 0.4427 & 0.3714 & 0.3267 \\
\hline
\end{tabular}

\section{DISCUSSION}

In medical practice, a prophylactic treatment is based on actions to prevent diseases. The main objectives of headache prophylaxis are to decrease the frequency, duration and intensity of the attacks; improve abortive medication's efficacy; make the patient's quality of life better and diminish his/her incapacity for daily activities. ${ }^{(10)}$ The prophylactic therapy of headache presents two strands: the pharmacological, which is composed by the betaadrenergic blockers, tricyclic antidepressants, calcium channel antagonists, anticonvulsants and others, and the non-pharmacological measures consist of physiotherapy, acupuncture, diet, among other. ${ }^{(11)}$

Tricyclic antidepressants are the most common drug used for headache prophylaxis. This class of antidepressant medication acts through downregulation and antagonism toward 5-HT2 receptors and reduction of beta-receptors' density. Moreover, it promotes the inhibition of epinephrine and serotonin reuptake, which increases these neurotransmitters' availability in gap and improves central antinociception by stimulating endogenous opioids. ${ }^{(10-12)}$

Tricyclic antidepressants are safe drugs for chronic renal patients, up to $1000 \mathrm{mg}$ per day (the dose for depression treatment). These drugs have a hepatic metabolization which is important for dialytic patients. Nortriptyline, desipramine and imipramine are better tolerated than amitriptyline by patients with CRD. ${ }^{(13)}$

In the present study, four patients abandoned the program. Only one left due to side effects (hypotension). The side effects found in this research were in accordance to the ones already described for tricyclic antidepressants. ${ }^{(10-12)}$ The most frequent are: vertigo syndrome, weight gain, increase in appetite, somnolence, dry mouth, intestinal constipation, neurogenic bladder, stained vision, reduction of convulsive threshold, tachycardia and akathisia. ${ }^{(10-12)}$

In the initial interviews, fifty-four percent (54\%) of the patients reported pain onset between the third and fourth hour of hemodialysis, similar to what Antoniazzi et al. ${ }^{(3)}$ found in their study $(62 \%$ of the patients presented the same onset pattern). The most prevalent pain intensity and location mentioned by our patients was throbbing frontal. This data is in keeping with the Göskan study from 2004. (14) In this study, the author described many characteristics of hemodialysis headache patients and found that the most frequent location of pain was frontotemporal $(50 \%)$ and the most frequent intensity was throbbing (87\%). ${ }^{(14)}$

After the use of prophylactic medication, there was no statistical significance in the change of the pain's onset and its total duration. However, there was a reduction of the pain's mean-time for each patient. There was a statistical significance in the difference of adjustable equations of frequency and intensity variables, but respective coefficient of determination values of these variables, obtained by linear regression, were low. It does not invalidate the information with Student's t test, but it exposes the fact that the adjustable model does not explain alternations of the dependent variables (frequency and intensity) properly. The frequency and intensity had such a large variation in a short time that more sustained observations are necessary.

In medical literature, there is only one case report of a possible prophylactic therapy for hemodialysis headache which used angiotensin-converting enzyme inhibitor without success. ${ }^{(8)}$ This study did not describe whether the prophylaxis modified the onset of pain, its mean duration or the frequency of attacks. The author reported that there was no decrease in pain's intensity and that, after 10 months of medication use, the treatment had to be interrupted because of side effects. ${ }^{(8)}$

\section{CONCLUSIONS}

It is important to find an efficient treatment for hemodialysis headache. Most of our patients reported pain in almost every session and, because of this, they tended to use abortive medications excessively which contributed to 
the pain's chronification. The results of this study are encouraging but insufficient to assure that the correct therapy for hemodialysis headache is tricyclic antidepressants, specifically nortriptyline.

Randomized, double-blinded, placebo-controlled studies with more patients must be executed to confirm or refute this research's data. For the time being, this study is the beginning of a new research line which seems to have promising results in the treatment of pain in hemodialysis headache patients.

\section{REFERENCES}

1. KDOQI. Clinical Practice Guidelines for Chronic Kidney Disease. Am J Kidney Dis. 2002;39:1-246.

2. Sesso RCC, Lopes AA, Thomé FS, Lugon JR, Burdmann EA. Censo Brasileiro de Diálise, 2009. J Bras Nefrol. 2010;32:380-4.

3. Antoniazzi AL, Bigal ME, Bordini CA, Speciali JG. Cefaléia relacionada à hemodiálise: análise dos possíveis fatores desencadeantes e do tratamento empregado. Arq Neuropsiquiatr 2002;60:614-8.

4. BBana DS, Yap AU, Graham JR. Headache during hemodialysis. Headache. 1972 Apr; 12(1): $1-14$.

5. Headache Classification Committee of the International Headache Society. Classification and diagnostic criteria for headache disorders, cranial neuralgias and facial pain. Cephalalgia 1988;8:1-96.

6. Headache Classification Committee of the International Headache Society (IHS) The International Classification of Headache Disorders, 3rd edition (beta version). Cephalalgia 2013; 33(9) 629-808.

7. Antoniazzi AL, Bigal ME, Bordini CA, Speciali JG. Headache associated with dialysis: the International Headache Society criteria revisited. Cephalalgia. 2003 Mar;23(2): 146-9.
8. Leinisch-Dahlke E, Schimidt-Wilcke T, Krämer BK, May A. Improvement of dialysis headache after treatment with ACEinhibitors but not angiotensin II receptor blocker: a case report with pathophysiological considerations. Cephalalgia. 2005 Jan;25(1):71-4.

9. Atkinson JH, Slater MA, Williams RA, Zisook S, Patterson TL, Grant l, et al. A placebo-controlled randomized clinical trial of nortriptyline for chronic low back pain. Pain. 1998 Jun;76(3): 287-96.

10. Silberstein SD. Preventive migraine treatment. Neurol Clin. 2009 May; 27(2):429-43.

11. Comite AD Hoc da Sociedade Brasileira de Cefaléia. Recomendações para o tratamento profilático da migrânea: Consenso da Sociedade Brasileira de Cefaléia. Arq Neuropsiquiatr. 2002;60(1):159-69.

12. Adelman JU, Adelman RD. Current options for prevention and treatment of migraine. Clin Ther. 2001 Jun;23(6):772-88.

13. Almeida AM, Meleiro AMAS. Depressão e insuficiência renal crônica: uma revisão. J Bras Nefrol 2000;22:192-200.

14. Göksan B, Karaali-Savrun F, Ertan S, Savrun M. Haemodialysis related headache. Cephalalgia. 2004 Apr;24(4):284-7.

$\overline{\text { Correspondência }}$

Paulo Sérgio Faro Santos Elnstituto de Neurologia de Curitiba Rua Jeremias Maciel Perretto, 300 $81210-310$ - Curitiba, PR, Brasil Fone/fax: + 413248.8580 dr.paulo.faro@gmail.com
Recebido: March, 032016 Aceito: March, 052016 